\title{
GROWTH OF SELECTED EAST ASIAN ECONOMIES: THE STRENGTH OF THE LINKS TO THE US AND EUROPE
}

As East Asian economies have traditionally been associated with export-oriented growth and development, this paper attempts to verify whether there indeed exist direct causal relations between certain East Asian (EA) countries on the one hand and the United States and Europe on the other in terms of the real gross domestic product (GDP). Specifically, their quarterly real gross domestic product (GDP) series spanning from 1999 are subjected to tests for their long run and short run lead-lag relations within a tri-variate modelling framework. Contrary to popular perception, the empirical evidence suggests that generally very nominal links exist between the GDP of these EA countries and that of the US. Direct links with Europe are found to be totally non-existent. All this would imply that the EA economies have a very limited susceptibility to shocks in the US and Europe, unless these shocks precipitate a global economic crisis of severe proportions such as the Great Recession. The growing conviction that when China sneezes, the world would catch a cold is also dispelled by the empirical results.

Keywords: causality, cointegration, growth;

JEL Classification: F41, F43

DOI: $10.15611 /$ aoe.2016.1.05

\section{INTRODUCTION}

It is generally perceived that the spectacular growth and development of East Asian (EA) economies over the past decades have been due to their adoption of the export-oriented development strategy, with the US and Western Europe being their major export destinations. Hence, if the Western economies now have to redress their burgeoning deficit phenomenon on the fiscal and external trade fronts, their continued dependability on such a strategy for growth and development would become questionable. Specifically, the Great Recession that began with the US sub-prime crisis in 2008 and was then followed by the European sovereign debt crisis has raised the issue that the EA economies might have to re-examine their long-term development strategies to ensure the sustainability of their economic growth

\footnotetext{
* Faculty of Economics and Administration, University of Malaya, Kuala Lumpur, Malaysia

** Centre for Policy Research and International Studies, Universiti Sains Malaysia, Penang, Malaysia
} 
momentum. Structural reforms in the US and Europe are perceived as a need by some to ensure global economic stability. Short of reform measures in the Western nations, the global economic community in general would be under constant threat to its stability. This is because as the fundamental weaknesses are left unaddressed and economic growth is restored merely by short-term macroeconomic stabilization policies, the underlying economic imbalances between the EA and the Western economies could emerge from time to time as a problem in the global economy. Thus though the global financial crisis may be over, the advanced countries in the West should not ignore the need to redress all the structural problems that led to the crisis by undertaking structural reforms to avert their reoccurrence.

Against this backdrop, this study aims to ascertain whether direct macroeconomic linkages actually exist between the US and alternately Europe (as collectively represented by the United Kingdom, Spain, Germany, Italy and France) on the one hand and some of the EA countries, namely Malaysia, Singapore, Thailand, the Philippines, Indonesia, Japan, South Korea, Hong Kong, China and Taiwan on the other. A tri-variate analysis of the natural logarithms of the real gross domestic product (GDP) of the US and alternately Europe, of China and of each of the other EA economies is pursued. A tri-variate model would not only allow us to explore the possibility of causal linkages that run from the US and Europe to the other economies which is the subject of our main concern but also those running from China to the US, Europe and the other EA economies. Cointegration and Granger causality are the principal concepts of causal relationships we meant.

Earlier studies on a similar theme, though that does not encompass Europe, by Tan (2012) and Tan and Tang (2013), merely involve bivariate modelling. Moreover, their sample periods span from the early 1990s which may give rise to the possibility of making inaccurate inferences as the EA economies have undergone dramatic structural transformations following the 1997/98 East Asian financial meltdown. It must also be noted that the significance of Europe and the US as their export markets has also been on the wane in recent years. Therefore it would be interesting to verify whether their GDP growth is still being largely driven by Europe and the US, particularly in the sense of cointegration and Granger causality.

To meet the objective of the paper, data over the period from 1999Q12011Q4 are drawn from the International Financial Statistics of the International Monetary Fund and the CEIC database. The rest of the paper is structured as follows. A general review of the related literature surrounding the EA economies is provided in the following section. Section 3 then 
provides an overview of the econometric methodology employed in the paper. The results of the econometric analysis are presented and discussed in Section 4 followed by concluding remarks in Section 5 .

\section{A BRIEF REVIEW OF THE LITERATURE ON EAST ASIAN ECONOMIES}

Generally, Thirlwall (1979) sees the balance-of-payments as a constraint on the output growth of a country. Exports are essential over the short to the medium term as they contribute to the relaxation of the balance-of-payments constraint. The availability of more international reserves accumulated from exports would enhance access to foreign made intermediate and capital goods which are growth facilitating. In recent decades, the fastest growing developing nations also largely happen to be the most successful exporters. A country cannot solely and indefinitely rely on inflows of foreign capital in the forms of aid or foreign direct investment. Such a dependency is merely sustainable in the short and not over a longer term. Predicated upon exportoriented industrialization, a number of EA economies have indeed enjoyed very impressive growth rates to such an extent of being viewed by the World Bank as a growth miracle (Hwang, et.al, 2013). In fact, it is the embarkation on export promotion rather than import substitution that largely explains the difference between the growth and development experience of the EA economies and that of the other, less successful developing ones. The exportled growth model has become the development template for the other developing economies. Their spectacular growth performance coupled with the considerable accumulation of current account surpluses amid the 2011 global recession has rendered the export-led growth model very appealing (Razmi and Hernandez, 2011).

Indeed the ability to export does not only contribute to the growth and development of an economy in terms of aggregate demand and foreign exchange augmentations. The advantages are rather manifold. Melitz (2003) views exports as harbingers of productivity growth through greater exposure to international competition, international knowledge spill-overs, economies of scale and other possible externalities. Generally exporting firms would be able to enjoy greater productivity gains compared with non-exporting ones (Greenaway and Kneller, 2007; Feder, 1983). Exports could thus serve as a catalyst for technological change and economic growth for a country. For example, East Asian exporters have faced the pressure to minimize cost and enhance efficiency due to international competition (Pack, 2001). By virtue 
of their international links, EA export-oriented firms have had greater access to new foreign technologies and technical guidance for meeting the stringent quality standards set by foreign importers especially when manufactured exports are concerned.

In most of these EA economies, there has been close inter-twining between their trade promotion and industrial development policies, such that their industrialization process has been dubbed as export oriented industrialization (EOI). For example, countries such as Malaysia and Singapore would grant very generous fiscal incentives to attract direct investors from developed countries to set up industrial operations in their shores. Foreign direct investment has contributed to the growth of many a developing country. Apart from fostering capital accumulation, foreign direct investment could serve as a vehicle for technology spillovers. For a developing country that is characterized by high marginal returns to capital with low-level technology, such potential benefits can be very tangible. In fact, countries such as Malaysia and Singapore have been in need of foreign direct investments more so for their production and marketing technologies and not so much for their funds as these countries have high domestic savings themselves.

The direction of exports matters also for the quantum of productivity gains that a country could enjoy from exporting. Productivity gains are generally larger amongst firms exporting to high income countries (De Loecker, 2007). This is explicable by the involvement of more stringent product quality standards, more sophisticated manufactured products and greater technical guidance when exporting to more rather than less advanced countries. Generally, consumers in developed countries are more discerning about product quality and safety standards than those in the less developed ones. Thus to be able to export more to developed countries would demand the ability to produce goods of superior quality. Greater knowledge spillovers and technology transfer and adoption of new management techniques may be witnessed by exporting to such countries (Razmi and Hernandez, 2011). This also appears to be true for the EA economies as their major trading partners are the Western advanced nations.

The significance of Western advanced nations to the growth and development of the EA economies may also be underscored by the phenomenon of international production fragmentation that generates crosscountry trading in parts and components. It is argued that the recent surge in intra-Asian trade has been due to this phenomenon. Parts and components are largely sourced from different EA locations and then assembled into final 
products in China to be exported extra-regionally (Athukorala and Yamashita, 2006). Thus the EA nations, apart from China, are in actual fact facing a derived demand for their products from Western economies. Macroeconomic developments in the US and Europe could still affect their growth trajectories. This would raise the question of whether China could indeed be the engine of growth for the region (Asian Development Bank, 2008; Haltmaier et al, 2007; and Ahearne, et al, 2006).

However, the belief that the EA economies have also become more independent of the West, particular of the US, has also gained traction in recent years. Growth in intra-regional trade and in domestic demand has been cited as providing the cushion to the EA economies from the impact of a slowdown in the US and the European economies (see Eichengreen and Park, 2008; World Bank, 2007). Dees and Vansteenkiste (2007) find that business cycle movements in the emerging Asia (excluding Japan) have become more independent of the US due to the rising role of China in the regional trade map. Park (2011) contends that increased intraregional trade would contribute to an East Asian region that is insulated from extraregional shocks. Hirata et al. (2013) find that there has been an increase in integration amongst nations in East Asia while their integration with nations beyond the region has been on the wane. Thus the EA economies could be less susceptible to shocks emanating from the US and Europe.

The relatively quick recovery of Asian economies from the 2008 global financial crisis is viewed by some as a decline in the synchronization of Asian output growth with the rest of the world especially the US (see Leduc and Spiegel, 2013). China fared well in the recovery process despite its openness and plummeting exports during the crisis. This is ascribable to the Chinese government's encouragement of its financial sector to embark upon large scale credit expansion in order to sustain its high growth in domestic output. In fact, the other EA economies also resorted to counter-cyclical macroeconomic policies by undertaking expansionary monetary policies and deficit fiscal policies - with the exception of South Korea. Generally, the maintenance of fiscal prudence and low government debts particularly after the 1997/98 EA financial crisis has allowed some EA governments greater fiscal headroom to respond to external economic shocks in recent years. Indeed the Asian economies with the exception of Japan were able to weather the crisis better than their Western counterparts who were constrained by their vexing financial difficulties and thus their limited scope for countercyclical policy manoeuvrability (see Spiegel, 2013).

In fact, the question of whether the developed economies could benefit from the robustness of the Asian economies in the recovery process has also 
been raised, specifically, whether Asian economies could constitute a substitute for the US as the driver of the global economy (Yetman, 2011). There is a perception amongst some economists that China could be leading the rest of the world to propel the US economy forward and aiding it to avert a recession (Bergsten, 2008). China is a major market for primary commodities from Asia and Latin America and for capital and electronic goods from the United States, Europe and Japan. It is maintained by the Asian Development Bank (ADB, 2011) that via its staging of a V-shaped recovery, it was a developing Asia that led the way out of the global financial doldrums and recession.

Generally, trade is seen as a channel of transmission of shocks from one country to another. According to the empirical findings of Frankel and Rose (1998), Clark and van Wincoop (2001) and Baxter and Kouparitsas (2005), greater bilateral trade between two countries would imply a greater correlation of their business cycles. In the context of this study, the significance of the US and Europe as export markets of the EA economies has somewhat waned in recent years. Hence in the light of these recent trends, it would be interesting to formally verify this using the econometric methodology whether macroeconomic developments in the US and Europe do have a significant bearing on the EA economies.

\section{METHODOLOGY}

Prior to testing for cointegration between the real GDP of each of the EA economies and that of the US and Europe, their orders of integration have to be first determined. It is contended by Perron (1989), that the standard unit root tests possess low power when structural breaks exist in the data series. This implies their tendency to accept the null hypothesis of a unit root. Thus before employing the standard tests, it is appropriate to first verify the existence of a unit root by subjecting the data series to the unit root test with two structural breaks as developed by Lumsdaine and Papell (1997). Perron (1989) maintains that most macroeconomic series either have structural breaks in the intercept of the trend function or structural breaks in the intercept and slope of the trend function. The Lumsdaine and Papell's models for unit root testing can be written as follows:

Model AA:

$$
\Delta y_{t}=\kappa+\alpha y_{t-1}+\beta t+\theta_{1} D U 1_{t}+\psi_{1} D U 2_{t}+\sum_{i=1}^{k} d_{i} \Delta y_{t-i}+\varepsilon_{t}
$$


Model CC:

$$
\begin{gathered}
\Delta y_{t}=\mu_{0}+\mu_{1} t+\mu_{2} D U 1_{t}+\mu_{3} D T 1_{t}+\mu_{4} D U 2_{t}+ \\
\mu_{5} D T 2_{t}+\delta y_{t-1}+\sum_{i=1}^{k} c_{i} \Delta y_{t-i}+e_{t}
\end{gathered}
$$

where $D U 1$ and $D U 2$ are dummy variables for structural breaks in the intercept occurring at times $T B 1$ and $T B 2$ respectively where $T B 2>T B 1$. DT1 and DT2 are dummy variables corresponding to changes in the trend $(t)$ variable. Specifically, the dummies are:

$$
D U 1_{t}=\left\{\begin{array}{l}
1 \text { if } t>T B 1 \\
0 \text { otherwise }
\end{array} \quad D T 1_{t}=\left\{\begin{array}{l}
t-T B 1 \text { if } t>T B 1 \\
0 \text { otherwise }
\end{array}\right.\right.
$$

and

$$
D U 2_{t}=\left\{\begin{array}{l}
1 \text { if } t>T B 2 \\
0 \text { otherwise }
\end{array} \quad D T 2_{t}=\left\{\begin{array}{l}
t-T B 2 \text { if } t>T B 2 \\
0 \text { otherwise }
\end{array}\right.\right.
$$

Following Hall's (1994) suggestion, this study selects the optimal lag length $(k)$ based upon the "t-significance" method and the break points (TBI and TB2) are identified where the ADF $t$-statistic is maximized in absolute terms. The GAUSS ${ }^{\mathrm{TM}}$ program code is relied upon to perform this unit root test with structural breaks.

The standard unit root tests may then be resorted to as supplements if the unit root test with structural breaks indeed suggests the existence of at least one unit root in the data series. The Augmented Dickey-Fuller (ADF) unit root test without any provision for structural breaks can be conducted by running the following auxiliary regressions:

$$
\begin{gathered}
\Delta y_{t}=\mu_{0}+\delta y_{t-1}+\sum_{i=1}^{k} \gamma_{i} \Delta y_{t-i}+\varepsilon_{t} \\
\Delta y_{t}=\mu_{0}+\mu_{1} t+\delta y_{t-1}+\sum_{i=1}^{k} \gamma_{i} \Delta y_{t-i}+\varepsilon_{t}
\end{gathered}
$$

Equation (3) can be relied upon to test the null hypothesis that a series (y) has a unit root against the alternative hypothesis that the series is mean stationary, whilst equation (4) can be used for testing the null hypothesis of a unit root against the alternative hypothesis that the series is trend stationary. If $y$ is non-stationary due to the presence of a unit root, $\delta$ will assume a zero value. The null hypothesis that $\delta=0$ can be tested by reference to the $t$-statistic, computed as the ratio of the estimated $\delta$ to its estimated standard error. This 
statistic is referred to as the Augmented Dickey-Fuller (ADF) statistic and its distribution does not follow the usual Student's $t$. The number of lags $(k)$ has to be optimally selected such that the regression is free from the problem of serial correlation. If $k=0$, the value of $t$ is simply referred to as the Dickey-Fuller statistic with its critical values similar to cases requiring augmentation. In practice however, it may not be correct to merely test whether a data series is I(1) or I(0) as an I(1) outcome does not necessarily imply that the series is indeed I(1). Hence the possibility that a series is integrated of higher order is also explored in line with Dickey and Pantula (1988), when conducting the test. The test then proceeds on the assumption that the highest possible order of integration of a series is 2 . Dickey and Pantula advocate that the unit root test be conducted on a series by moving from the highest to the lowest level of differentiating contemplated in the series, following a sequence of one-sided tests.

Rather than incorporating additional lagged terms in regression equations (3) and (4) such that they are free from serial correlation when conducting the ADF test, Phillips and Perron (1988), suggest making a non-parametric correction to the standard statistics instead. Thus while the ADF procedure is based upon the presence of only white noise errors in the regression equations, the Phillips-Perron (PP) approach involves the modification of the statistics after estimation in order to account for the effect of auto-correlated errors on the test outcomes. In other words, the error term is not assumed to be white noise in the PP procedure.

In order to establish whether long-run relations exist amongst the real GDPs of countries, let us say A, B and C, the Johansen cointegration technique is applied. Generally, this involves estimating a vector error correction model (VECM) as follows:

$$
\Delta Y_{t}=\phi D+\Pi Y_{t-k}+\sum_{i=1}^{k-1} \theta_{i} \Delta Y_{t-i}+\varepsilon_{t}
$$

In a tri-variate case as in this study, $Y_{t}$ would be a vector comprising the real GDPs of three countries $\left(y_{A t}, y_{B t}\right.$ and $\left.y_{C t}\right)$.Hence $\phi, \Pi$ and $\theta$ would then be $3 \times 3$ matrices of unknown parameters to be estimated with $\varepsilon_{t}$ being the error-term. The long-run relationship amongst $y_{A t}, y_{B t}$ and $y_{C t}$ will be captured by the impact matrix, $\Pi$. If the real GDPs are integrated of order one, the cointegrating rank, $r$, would be given by the rank of $\Pi=\alpha \beta^{\prime}$ where $\alpha$ captures the speed of convergence to the long-run equilibrium, while $\beta$ contains parameters in the cointegrating vector. To test for the presence of 
cointegrating vectors, two likelihood ratio (LR) tests are suggested by Johansen (1988) and Johansen and Juselius (1990). They are the trace test $L R\left(\lambda_{\text {trace }}\right)=-T \sum_{i=r+1}^{k} \ln \left(1-\lambda_{i}\right)$, and the maximum eigenvalue test $L R\left(\lambda_{\max }\right)=-T \ln \left(1-\lambda_{i+1}\right)$, where $\lambda_{i}$ are the eigenvalues and $T$ is the number of observations. In empirical applications however, the trace test statistic is commonly regarded as superior to the maximum eigenvalue test statistic.

If the variables, $y_{A t}, y_{B t}$ and $y_{C t}$ are not cointegrated, the Granger causality test may be conducted simply based upon a first difference vector auto-regression (VAR) model. However if there exists cointegration, the test should be conducted based upon a VECM to account for the long run causation as well (Granger, 1988). This involves the incorporation of the one period lagged error-correction term $\left(E C_{t-1}\right)$ into the first difference VAR model as follows:

$$
\begin{aligned}
& \Delta y_{A t}=\alpha_{1}+\sum_{i=1}^{k} b_{i} \Delta y_{A t-i}+\sum_{i=1}^{k} c_{i} \Delta y_{B t-i}+\sum_{i=1}^{k} d_{i} \Delta y_{C t-i}+\lambda_{1} E C_{t-1}+v_{1 t} \\
& \Delta y_{B t}=\alpha_{2}+\sum_{i=1}^{k} e_{i} \Delta y_{A t-i}+\sum_{i=1}^{k} f_{i} \Delta y_{B t-i}+\sum_{i=1}^{k} g_{i} \Delta y_{C t-i}+\lambda_{2} E C_{t-1}+v_{2 t} \\
& \Delta y_{C t}=\alpha_{3}+\sum_{i=1}^{k} h_{i} \Delta y_{A t-i}+\sum_{i=1}^{k} m_{i} \Delta y_{B t-i}+\sum_{i=1}^{k} p_{i} \Delta y_{C t-i}+\lambda_{3} E C_{t-1}+v_{3 t}
\end{aligned}
$$

where $E C_{t-1}$ is derived from the cointegrating vector, the residuals $v_{1 t}, v_{2 t}$ and $v_{3 t}$ are assumed to be normally distributed with white noise and $k$ the optimal lag length determined based upon the Akaike Information Criterion (AIC). The statistical significance of $E C_{t-1}$ would indicate long-run causality, while the joint significance of the lags of the first difference of the explanatory variables would represent short-run causality. From equation (6), $c_{1} \neq c_{2} \neq \ldots \neq c_{k} \neq 0$ and $d_{1} \neq d_{2} \neq \ldots \neq d_{k} \neq 0$ imply that $y_{B t}$ and $y_{C t}$ respectively Granger-cause $y_{A t}$. From equation (7), $e_{1} \neq e_{2} \neq \ldots \neq e_{k} \neq 0$ and $g_{1} \neq g_{2} \neq \ldots \neq g_{k} \neq 0$ would respectively indicate that $y_{A t}$ and $y_{C t}$ Grangercause $y_{B t}$. And finally from equation (8), $h_{1} \neq h_{2} \neq \ldots \neq h_{k} \neq 0$ and $m_{1} \neq m_{2} \neq \ldots \neq m_{k} \neq 0$ would mean that $y_{A t}$ and $y_{B t}$ Granger-cause $y_{C t}$. 


\section{EMPIRICAL OUTCOMES}

Table 1 presents the results of the Lumsdaine-Papell unit root test. In spite of provisions for possible structural breaks, the results indicate that there is a unit root in all the data series. Hence, it can be inferred that they are inherently not integrated of order zero, I(0). The results of the DickeyFuller-based and the Phillips-Perron unit root tests are furnished in Table 2. In conducting the former, a maximum possible lag order of 4 is allowed for. For levels of the data series, both a trend and a constant are included in the auxiliary regression. As for first and second differences, the trend term is excluded. The critical values for the tests are computed by bootstrapping. The optimal lag order is selected generally based upon the Akaike Information Criterion (AIC). It can be inferred from the table that the Dickey-Fuller based test suggests that all the real GDP series are integrated of order one, I(1), i.e. they are different rather than trend stationary except for those of Malaysia, Thailand and Taiwan which are I(0). A higher order of integration is ruled out by the test based upon second differences. However, the Phillips-Perron test would suggest that those of the Philippines, Hong Kong and China are $\mathrm{I}(0)$ while upholding those of others as I(1). Notwithstanding this, since real GDP series are commonly found to be I(1) rather than $\mathrm{I}(0)$ and given that the Lumsdaine-Papell test has revealed that all the GDP series herein cannot be I(0), we shall then regard them as I(1).

In view of this, the Johansen cointegration test is performed based upon a tri-variate model involving the real GDP of the US and alternately Europe, of China and of each of the other EA economies successively. The usual contentious issue that arises is on the inclusion of an intercept and a trend in the short and/or long-run models. Johansen (1992), suggests testing of the joint hypotheses of both the rank order and the deterministic components following the Pantula principle. Hence, three models are estimated in this study, viz. with restricted intercepts and no trends in the VAR (M1), unrestricted intercepts and no trends in the VAR (M2) and unrestricted intercepts and restricted trends in the VAR (M3). Centred seasonal dummies are included in the estimation. The maximum possible lag order is set at 4 with the optimal lag order determined based largely upon the AIC. The testing process involves switching from the most to a less restrictive model, with the process ending at a point when a null hypothesis is accepted. Tables 3 and 4 present the trace statistics of the Johansen cointegration test vis-à-vis the U.S and Europe respectively. Apart from the real GDP of each individual EA economy, attempts are also made to test for long-run relationships based 
upon an aggregation of their real GDPs but excluding that of China (EAEC). Table 3 would suggest the existence of a cointegrating relationship only amongst Thailand, China and the US and amongst Taiwan, China and the US, while none with respect to the other EA economies. However, the estimated long-run coefficient of the US output in the Thai output equation is statistically insignificant. Cointegration between the real GDP of each of the EA economies and that of Europe is totally ruled out by Table 4. Hence, it can be inferred that only a long-run relationship exists between the real GDP of Taiwan and that of the US - contrary to popular expectations.

Given the absence of cointegration except for the case of Taiwan, shortrun Granger causal relations can be established based simply upon a standard Vector Auto-regression (VAR) model. In the case of Taiwan, the Vector Error Correction Modelling (VECM) framework applies. The various VAR models are estimated with the incorporation of deterministic seasonal dummies with the maximum possible lag order set at 4 . The optimal lag order is also determined largely based upon the AIC. The results of the test are presented in Tables 5 and 6 with respect to the US and Europe respectively. It is interesting to note that unlike the issue of long-run relations addressed in the preceding section, there seems to be a greater prevalence of short-run unidirectional Granger causal relations running from the US to the EA economies except for Thailand and Indonesia as indicated by the likelihood ratio and F-statistics. While there seems to be Granger causal links from the US to China as alluded to by almost all the estimated tri-variate models, a reverse Granger causality from China to the US is completely ruled out. Granger causal relations between the EA economies and Europe of either direction are totally non-existent as highlighted by Table 6. In the course of testing for Granger causality, additional tests are also performed to ascertain whether (i) China could also be dependent upon Japan and Korea for economic growth as these are wealthy economies and on all the other EA economies as a whole (EAEC); and (ii) whether the other EA economies are dependent upon China. The results proved negative for these.

As there exist Granger causal links from the US to all the EA economies, except for Thailand and Indonesia, it is interesting to assess the strength of the links based upon the generalized impulse response functions. This can be affected by looking at the impact on the output growth of these EA economies of a unit shock of one standard error in magnitude administered to the corresponding US output growth equation. Figures 1 and 2 are plots of the impulse response functions for these countries over a 20-period horizon. 
The plot for China in Figure 2 is based upon the estimated tri-variate model involving the EAEC, China and the US. The shock to the US growth seems to have had only a nominal impact on the output growth of these economies with the effect decaying very rapidly in some cases. At horizon 1, the effect is hardly 2 per cent in magnitude.

\section{CONCLUSIONS}

This paper primarily attempts to verify whether the growth of the East Asian economies has been driven by the US and Europe in line with the traditional conviction that the EA economies have flourished from their external led development strategies. Its empirical results, however, rule out completely direct links in terms of GDP between the EA economies and Europe while revealing nominal links between the former and the US. Specifically only the Taiwanese GDP seems to have a long-run relation with that of the US. Though there exist short-run Granger causal relations spanning from the US to all the EA economies except Thailand and Indonesia, an inspection of the generalised impulse response functions reveals that even such links are weak. A unit shock administered to the US output growth would only have a nominal impact on their economic growth. Such empirical outcomes should not be seen as being inconsistent with the experience of economic recession by these countries as a consequence of the US financial crisis in 2008-2009. They suffered the recession simply because the US crisis deteriorated into a global economic crisis, dubbed as the Great Recession. There were serious disruptions to international capital flows and a number of countries witnessed the collapse of their stock markets and a liquidity crunch in their banking systems. According to Korinek, Roitman and Vegh (2010), the US sub-prime crisis began to spread like wildfire around May 2008, particularly after the collapse of Lehman on September 15, 2008. It engulfed countries world-wide involving collapses of asset and stock prices in unison.

The US crisis was subsequently followed by the European sovereign debt crisis. Though a number of the EA economies experienced a slowdown in their exports to Europe, the dent on their macroeconomic performance was insignificant by casual observations. Thus the empirical results of the paper which are related to Europe also do seem to be consistent with reality. Generally the EA economies appear to be quite resilient to the crisis in the US and Europe. They quickly resumed their usual growth path due to export market diversification and increased domestic consumption and investment, 
particularly in infrastructure development. The significance of the US and Europe as their export markets has diminished over the years.

Following the 1997-1998 EA financial crisis, they started focusing on the need to enhance their economic resilience. Intra-regional trade was promoted and due to fiscal prudence in good times, they were able to devise fiscal stimulus packages that insulated their economies from the recent economic crisis in the West. Loose monetary policies were also observed as a countercyclical policy supplement. Notwithstanding this, it remains imperative for them to strive for even greater resilience. There cannot be indefinite reliance on fiscal stimulus and low interest rate policies. Structural reforms that involve boosting domestic consumption and wage reforms that would enable wages to grow in tandem with productivity need to be instituted. Underconsumption in these countries has resulted from the maintenance of high precautionary savings amongst households due to inadequate public provisions of healthcare, housing and education (Akyûz, 2011).

The tri-variate modelling approach of the paper has also allowed us to address the growing conviction amongst certain quarters that if China sneezes, the world would catch a cold. This is based upon the observed increase in China's trade relations with the rest of the world, especially Asia. Hence, the state of China's economy could make an impact on the rest with exports and commodity prices being the transmission channel. This is however not borne out by the econometric results, as no Granger causal relations are observed to run from China to the US, Europe and other EA economies. Nevertheless, such results could stem from the fact that China only began to trade more with these economies in recent years. China's emergence as a global economic player is only a recent development.

\section{REFERENCES}

Ahearne, A. G., Fernald, J. G., Loungani, P., Schindler, J. W., Flying Geese or Sitting Ducks: China's Impact on the Trading Fortunes of Other Asian Countries, "International Finance Discussion Paper" 886. Board of Governors of Federal Reserve System, Washington, DC, 2006.

Akyüz, Y., Export Dependence and Sustainability of Growth in China, "China \& World Economy", 19(1), pp.1-23, 2011.

Asian Development Bank (ADB), Outlook 2008: Highlights, Manila 2008.

Asian Development Bank (ADB), Asia 2050: Realising the Asian Century, Manila 2011.

Athukorala, P., Yamashita, N., Production Fragmentation and Trade Integration: East Asia in a Global Context, "North American Journal of Economics and Finance", 17(3), pp. 1-24, 2006. 
Baxter, M., Kouparitsas, M. A., Determinants of Business Cycle Comovement: A Robust Analysis, "Journal of Monetary Economics", 52(1), pp. 113-157, 2005.

Bergsten, F., "Trade Has Saved America from Recession, "Financial Times", 2008.

Clark, T., van Wincoop, E., Borders and Business Cycles, "Journal of International Economics", 55(1), pp. 59-85, 2001.

Dees, S., Vansteenkiste, I., The Transmission of US Cyclical Developments to the Rest of the World, "European Central Bank Working Paper" 798, 2007.

De Loecker, J., Do Exports Generate Higher Productivity? Evidence from Slovenia, "Journal of International Economics", 73(1), pp. 69-98, 2007.

Dickey, D. A., Pantula, S. G., Determining the Order of Differencing in Autoregressive Processes, "Journal of Business and Economic Statistics", 5, pp.455-61, 1988.

Eichengreen, B., Park, Y. C., Asia and the Decoupling Myth, 2008. [Internet] Available at: http:// www.econ.berkeley.edu/\%7Eeichengr/asia_decoup_myth.pdf $>$ [Accessed 20 January 2010).

Feder, G., On Exports and Economic Growth, "Journal of Development Economics”, 12(1-2), pp. 59-73, 1983.

Frankel, J. A., Rose, A. K., The Endogeneity of the Optimum Currency Area Criteria, "Economic Journal", 108(449), pp.1009-1025, 1998.

Granger, C. W. J., Some Recent Developments in a Concept of Causality, "Journal of Econometrics", 39, pp. 199-211, 1988.

Greenaway, D., Kneller, R., Industry Differences in the Effect of Export Market Entry: Learning by Exporting?, "Review of World Economics", 143(3), pp. 416-432, 2007.

Hall, A. D., Testing for a Unit Root in Time Series with Pretest Data based on Model Selection, "Journal of Business \& Economic Statistics", 12(4), pp.461-470, 1994.

Haltmaier, J. T., Ahmed, S., Coulibaly, B., Knippenberg, R., Leduc, S., Marazzi, M.,Wilson, B. A. 2007. The Role of China in Asia: Engine, Conduit or Steamroller?, "International Finance Discussion Papers" 904, 2007.

Hirata, H., Kose, A., Otrok, C., Regionalization vs. Globalization, Federal Reserve Bank St. Louis Working Paper, 2013-002A.

Hwang, K. M., Park, D., Shin, K., Capital Market Openness and Output Volatility, "Pacific Economic Review", 18(3), pp. 403-430, 2013.

Johansen, S., Statistical Analysis of Cointegration Vectors, "Journal of Economics Dynamics and Control", 12(2-3), pp. 231-254, 1988.

Johansen, S., Determination of Cointegration Rank in the Presence of a Linear Trend, "Oxford Bulletin of Economics and Statistics", 54(3), pp. 383-971, 1992.

Johansen, S., Juselius, K., Maximum Likelihood Estimation and Inference on Cointegration with Applications to the Demand for Money, "Oxford Bulletin of Economics and Statistics", 52(2), pp. 169-210, 1990.

Korinek, A., Roitman, A., Végh, C. A., Decoupling and Recoupling, “American Economic Review", 100(2), pp. 393-397, 2010.

Leduc, S., Spiegel, M. M., Is Asia Decoupling from the United States (again)?, "Pacific Economic Review", 18(3), pp. 345-369, 2013. 
Lumsdaine, R., Papell, D., Multiple Trend Breaks and the Unit Root Hypothesis, "Review of Economics and Statistics", 79(2), pp. 212-218, 1997.

Melitz, M., The Impact of Trade on Intra-Industry Reallocations and Aggregate Industry Productivity, "Econometrica", 71(6), pp. 1695-1725, 2003.

Pack, H., Technological Change and Growth in East Asia: Macro versus Micro-perspectives [in:] Stiglitz, J., Yusuf, S. (eds.), Rethinking the East Asian Miracle. Oxford University Press, Oxford 2001.

Park, Y. C., The Global Financial Crisis: Decoupling of East Asia-myth or Reality?, ADBI Working Paper Series 289, 2011.

Perron, P., The Great Crash, the Oil Price Shock and the Unit Root Hypothesis, "Econometrica", 57(6), pp. 1361-1401, 1989.

Phillips, P. C. B., Perron, P., Testing for a Unit Root in Time Series Regression, "Biometrika", 75, pp. 335-346, 1988.

Razmi, A., Hernandez, G., Can Asia Sustain an Export-Led Growth Strategy in the Aftermath of the Global Crisis? An Empirical Exploration, Asian Development Bank Institute Working Paper Series 329, 2011.

Spiegel, M. M., Introduction: Asian Business Cycle Synchronization with the Global Economy, "Pacific Economic Review", 18(3), pp. 318-320, 2013.

Tan, E. C., Direct Macroeconomic Links between Selected East Asian Economies and the US? An Empirical Analysis, "Singapore Economic Review", 57(3), pp. 1-9, 2012.

Tan, E. C.,Tang, C. F., The Extent of Growth Dependence of Selected East Asian Economies on the USA, "Global Economic Review", 42(1), pp. 43-54, 2013.

Thirlwall, A. P., The Balance of Payments Constraint as an Explanation of International Growth Rate Differences, "Banca Nazionale del Lavoro Quarterly Review", 32(128), pp. 45-53, 1979.

World Bank, Will Resilience Overcome Risk? East Asia and Pacific Update. World Bank, Washington, DC 2007.

Yetman, J., The Decoupling of Asia-Pacific? [in:] Cheung, W. Y., Kaaker, V., Ma, G. (eds.), The Evolving Role of Asia in Global Finance, Frontiers of Economics and Globalization. Emerald, Bingley, West Yorkshire 2011.

Received: May 2015, revised: November 2015

Acknowledgement: The authors wish to express their sincere appreciation to the two anonymous reviewers for their valuable comments and suggestions on this paper, without implicating them for whatever shortcomings that remain. 


\section{APPENDIX}

Table 1

Lumsdaine-Papell Unit Root Test

\begin{tabular}{|c|c|c|c|c|}
\hline \multirow[b]{2}{*}{ Real GDP Series of } & \multicolumn{2}{|c|}{ Model AA } & \multicolumn{2}{|c|}{ Model CC } \\
\hline & $\begin{array}{c}\text { Test } \\
\text { statistics }\end{array}$ & $\begin{array}{l}T B 1 \\
T B 2 \\
\end{array}$ & $\begin{array}{c}\text { Test } \\
\text { statistics }\end{array}$ & $\begin{array}{l}T B 1 \\
T B 2\end{array}$ \\
\hline China & $-0.48(12)$ & \begin{tabular}{|l|} 
2004:Q4 \\
2010:Q2 \\
\end{tabular} & $-3.91(12)$ & $\begin{array}{l}\text { 2006:Q3 } \\
\text { 2010:Q2 }\end{array}$ \\
\hline Europe & $-5.32(8)$ & $\begin{array}{l}\text { 2008:Q3 } \\
\text { 2010:Q2 }\end{array}$ & $-5.28(1)$ & $\begin{array}{l}2002: Q 1 \\
\text { 2008:Q3 }\end{array}$ \\
\hline Hong Kong & $-4.81(5)$ & \begin{tabular}{|l|} 
2005:Q1 \\
2006:Q2 \\
\end{tabular} & $-5.28(9)$ & $\begin{array}{l}\text { 2004:Q2 } \\
\text { 2007:Q2 }\end{array}$ \\
\hline Indonesia & $-3.07(11)$ & \begin{tabular}{|l|} 
2007:Q1 \\
2010:Q2
\end{tabular} & $-6.60(4)$ & $\begin{array}{l}2005: Q 3 \\
\text { 2008:Q3 } \\
\end{array}$ \\
\hline Japan & $-4.61(5)$ & $\begin{array}{l}\text { 2009:Q1 } \\
\text { 2010:Q1 }\end{array}$ & $-6.23(7)$ & $\begin{array}{l}2006: Q 4 \\
2008: Q 2\end{array}$ \\
\hline Malaysia & $-5.50(4)$ & $\begin{array}{l}2007: Q 1 \\
\text { 2010:Q2 }\end{array}$ & $-6.41(7)$ & $\begin{array}{l}\text { 2006:Q1 } \\
\text { 2008:Q3 }\end{array}$ \\
\hline Philippines & $-4.70(11)$ & \begin{tabular}{|l|} 
2005:Q4 \\
2007:Q1
\end{tabular} & $-6.04(4)$ & $\begin{array}{l}\text { 2004:Q1 } \\
\text { 2009:Q1 }\end{array}$ \\
\hline Singapore & $-4.46(4)$ & $\begin{array}{l}\text { 2005:Q1 } \\
\text { 2006:Q1 }\end{array}$ & $-6.19(4)$ & $\begin{array}{l}2004: Q 2 \\
\text { 2008:Q3 }\end{array}$ \\
\hline South Korea & $-5.83(2)$ & $\begin{array}{l}\text { 2005:Q2 } \\
\text { 2008:Q3 }\end{array}$ & $-6.09(12)$ & $\begin{array}{l}2004: Q 2 \\
\text { 2008:Q1 }\end{array}$ \\
\hline Taiwan & $-5.66(7)$ & $\begin{array}{l}\text { 2002:Q4 } \\
\text { 2008:Q2 }\end{array}$ & $-5.98(8)$ & $\begin{array}{l}2008: Q 2 \\
2009: Q 3\end{array}$ \\
\hline Thailand & $-5.05(4)$ & $\begin{array}{l}\text { 2004:Q3 } \\
\text { 2006:Q2 }\end{array}$ & $-4.71(8)$ & $\begin{array}{l}\text { 2004:Q1 } \\
\text { 2009:Q4 }\end{array}$ \\
\hline United States & $-3.89(2)$ & \begin{tabular}{|l} 
2004:Q2 \\
2008:Q1
\end{tabular} & $-6.21(9)$ & $\begin{array}{l}\text { 2003:Q2 } \\
\text { 2007:Q2 }\end{array}$ \\
\hline \multicolumn{5}{|c|}{ Asymptotic critical values } \\
\hline 1 per cent & -6.74 & & -7.19 & \\
\hline 5 per cent & -6.16 & & -6.75 & \\
\hline
\end{tabular}

Notes: Figures in parentheses ( ) refer to the optimal lag length. The asymptotic critical values are drawn from Lumsdaine and Papell (1997).

Source: authors' own 
Table 2. Standard Unit Root Tests

\begin{tabular}{l|r|r|r|r|r|r}
\hline \multirow{2}{*}{ Real GDP Series of } & \multicolumn{2}{|c}{ Dickey-Fuller/Augmented Dickey-Fuller } & \multicolumn{3}{c}{ Phillips-Perron } \\
\cline { 2 - 7 } & \multicolumn{1}{c}{ Level } & $\mathbf{1}^{\text {st }}$ Difference & $\mathbf{2}^{\text {nd }}$ Difference & \multicolumn{1}{c}{ Level } & $\mathbf{1}^{\text {st }}$ Difference & $\mathbf{2}^{\text {nd }}$ Difference \\
\hline United States (US) & $-2.048(0)$ & $-5.610^{*}(0)$ & $-8.138^{*}(2)$ & -0.975 & $-5.543^{*}$ & $-9.799^{*}$ \\
\hline Europe (EUR) & $-2.221(1)$ & $-5.305^{*}(1)$ & $-6.682^{*}(4)$ & -1.403 & $-4.887^{*}$ & $-8.448^{*}$ \\
\hline Malaysia (MAL) & $-3.533^{*}(4)$ & $-3.708^{*}(4)$ & $-5.345^{*}(3)$ & -2.149 & $-5.802^{*}$ & $-9.375^{*}$ \\
\hline Thailand (THA) & $-3.450^{*}(4)$ & $-6.843^{*}(1)$ & $-11.637^{*}(2)$ & -2.802 & $-5.196^{*}$ & $-8.131^{*}$ \\
\hline Philippines (PHI) & $-2.031(4)$ & $-3.424^{*}(4)$ & $-4.977^{*}(3)$ & $-3.405^{*}$ & $-14.557^{*}$ & $-24.051^{*}$ \\
\hline South Korea (KOR) & $-3.087(4)$ & $-4.076^{*}(4)$ & $-5.195^{*}(3)$ & -2.829 & $-8.886^{*}$ & $-15.253^{*}$ \\
\hline Japan (JAP) & $-2.648(4)$ & $-3.367^{*}(2)$ & $-9.204^{*}(2)$ & -1.591 & $-6.772^{*}$ & $-9.548^{*}$ \\
\hline Indonesia (IND) & $-2.714(0)$ & $-10.161^{*}(0)$ & $-11.656^{*}(2)$ & -2.641 & $-7.950^{*}$ & $-13.778^{*}$ \\
\hline Hong Kong (HK) & $-3.307(4)$ & $-3.371^{*}(3)$ & $-24.867^{*}(2)$ & $-5.383^{*}$ & $-7.680^{*}$ & $-8.492^{*}$ \\
\hline China (CH) & $-0.088(4)$ & $-4.960^{*}(3)$ & $-7.733^{*}(4)$ & $-8.089^{*}$ & $-10.803^{*}$ & $-13.450^{*}$ \\
\hline Taiwan (TAI) & $-4.107 *(4)$ & $-3.948^{*}(4)$ & $-11.549^{*}(2)$ & -2.985 & $-6.616^{*}$ & $-9.238^{*}$ \\
\hline Singapore (SIN) & $-2.923(4)$ & $-3.382^{*}(4)$ & $-4.515^{*}(3)$ & -1.985 & $-6.336^{*}$ & $-10.477^{*}$ \\
\hline EAEC** & $-2.860(4)$ & $-3.421^{*}(2)$ & $-9.778^{*}(2)$ & -1.598 & $-6.459^{*}$ & $-9.350^{*}$ \\
\hline
\end{tabular}

Notes: * Statistically significant at the $5 \%$ level. ** The East Asian economies as a whole (excluding China). Figures in (.) refer to the optimal lag order.

Source: authors' own

Table 3. Cointegration Test (vis-à-vis the US)

\begin{tabular}{l|c|c|c|c|c}
\hline Country & Model & VAR Order & Null Hypothesis & Trace Statistics & 95\% Critical Value \\
\hline MAL & 2 & 2 & $\mathrm{r}=0$ & 31.218 & 31.54 \\
\hline THA & 2 & 1 & $\mathrm{r}=1$ & 14.390 & 17.86 \\
\hline PHI & 2 & 2 & $\mathrm{r}=0$ & 31.360 & 31.54 \\
\hline KOR & 2 & 2 & $\mathrm{r}=0$ & 31.217 & 31.54 \\
\hline JAP & 2 & 4 & $\mathrm{r}=0$ & 29.424 & 31.54 \\
\hline IND & 2 & 2 & $\mathrm{r}=0$ & 28.359 & 31.54 \\
\hline HK & 2 & 2 & $\mathrm{r}=0$ & 30.107 & 31.54 \\
\hline TAI & 2 & 4 & $\mathrm{r}=1$ & 15.203 & 17.86 \\
\hline SIN & 2 & 4 & $\mathrm{r}=0$ & 31.001 & 31.54 \\
\hline EAEC & 2 & 4 & $\mathrm{r}=0$ & 30.601 & 31.54 \\
\hline
\end{tabular}

Source: authors' own

Table 4. Cointegration Test (vis-à-vis Europe)

\begin{tabular}{l|c|c|c|c|c}
\hline Country & Model & VAR Order & Null Hypothesis & Trace Statistics & 95\% Critical Value \\
\hline MAL & 1 & 2 & $\mathrm{r}=0$ & 24.534 & 34.87 \\
\hline THA & 1 & 1 & $\mathrm{r}=0$ & 30.154 & 34.87 \\
\hline PHI & 1 & 3 & $\mathrm{r}=0$ & 27.135 & 34.87 \\
\hline KOR & 1 & 2 & $\mathrm{r}=0$ & 20.827 & 34.87 \\
\hline JAP & 2 & 4 & $\mathrm{r}=0$ & 22.197 & 31.54 \\
\hline IND & 1 & 1 & $\mathrm{r}=0$ & 27.955 & 34.87 \\
\hline HK & 1 & 2 & $\mathrm{r}=0$ & 30.202 & 34.87 \\
\hline TAI & 2 & 4 & $\mathrm{r}=0$ & 28.118 & 31.54 \\
\hline SIN & 1 & 2 & $\mathrm{r}=0$ & 23.715 & 34.87 \\
\hline EAEC & 2 & 4 & $\mathrm{r}=0$ & 24.016 & 31.54 \\
\hline
\end{tabular}

Source: authors' own 
Table 5. Granger Causality Test (vis-à-vis the US)

\begin{tabular}{|c|c|c|c|c|}
\hline Country & Lag Order & Null Hypothesis & $\begin{array}{l}\text { Likelihood Ratio } \\
\text { Test Statistic }\left(\chi^{2}\right)\end{array}$ & F-statistic \\
\hline \multirow[t]{4}{*}{ MAL } & \multirow[t]{4}{*}{1} & $\mathrm{US} \rightarrow \mathrm{MAL}$ & $6.873[0.009]$ & $6.359[0.015]$ \\
\hline & & $\mathrm{CH} \nrightarrow \mathrm{MAL}$ & $0.045[0.832]$ & $0.039[0.844]$ \\
\hline & & $\mathrm{CH} \nrightarrow \mathrm{US}$ & $0.240[0.624]$ & $0.208[0.650]$ \\
\hline & & $\mathrm{US} \rightarrow \mathrm{CH}$ & $4.387[0.036]$ & $3.961[0.053]$ \\
\hline \multirow[t]{4}{*}{ THA } & \multirow[t]{4}{*}{1} & US $\nrightarrow$ THA & $0.530[0.467]$ & $0.461[0.501]$ \\
\hline & & $\mathrm{CH} \nrightarrow \mathrm{THA}$ & $0.590[0.443]$ & $0.513[0.477]$ \\
\hline & & $\mathrm{CH} \nrightarrow \mathrm{US}$ & $0.320[0.572]$ & $0.278[0.601]$ \\
\hline & & $\mathrm{US} \nrightarrow \mathrm{CH}$ & $4.025[0.045]$ & $3.621[0.063]$ \\
\hline \multirow[t]{4}{*}{ PHI } & \multirow[t]{4}{*}{1} & $\mathrm{US} \nrightarrow \mathrm{PHI}$ & $6.349[0.012]$ & $5.844[0.020]$ \\
\hline & & $\mathrm{CH} \nrightarrow \mathrm{PHI}$ & $3.245[0.072]$ & $2.897[0.096]$ \\
\hline & & $\mathrm{CH} \nrightarrow \mathrm{US}$ & $0.046[0.831]$ & $0.039[0.844]$ \\
\hline & & $\mathrm{US} \rightarrow \mathrm{CH}$ & $4.045[0.044]$ & $3.640[0.063]$ \\
\hline \multirow[t]{5}{*}{ KOR } & \multirow[t]{5}{*}{1} & $\mathrm{US} \nrightarrow \mathrm{KOR}$ & $6.831[0.009]$ & $6.317[0.016]$ \\
\hline & & $\mathrm{CH} \nrightarrow \mathrm{KOR}$ & $0.750[0.387]$ & $0.654[0.423]$ \\
\hline & & $\mathrm{CH} \nrightarrow \mathrm{US}$ & $0.255[0.613]$ & $0.222[0.640]$ \\
\hline & & $\mathrm{US} \nrightarrow \mathrm{CH}$ & $3.926[0.048]$ & $3.529[0.067]$ \\
\hline & & $\mathrm{KOR} \nrightarrow \mathrm{CH}$ & $0.906[0.341]$ & $0.791[0.379]$ \\
\hline \multirow[t]{5}{*}{ JAP } & \multirow[t]{5}{*}{3} & $\mathrm{US} \nrightarrow \mathrm{JAP}$ & $10.491[0.015]$ & $2.906[0.047]$ \\
\hline & & $\mathrm{CH} \nrightarrow \mathrm{JAP}$ & $3.487[0.322]$ & $0.902[0.449]$ \\
\hline & & $\mathrm{CH} \nrightarrow \mathrm{US}$ & $1.155[0.764]$ & $0.292[0.831]$ \\
\hline & & $\mathrm{US} \nrightarrow \mathrm{CH}$ & $9.316[0.025]$ & $2.551[0.070]$ \\
\hline & & $\mathrm{JAP} \nrightarrow \mathrm{CH}$ & $0.756[0.860]$ & $0.190[0.902]$ \\
\hline \multirow[t]{4}{*}{ IND } & \multirow[t]{4}{*}{1} & $\mathrm{US} \nrightarrow \mathrm{IND}$ & $1.212[0.271]$ & $1.061[0.308]$ \\
\hline & & $\mathrm{CH} \nrightarrow \mathrm{IND}$ & $0.606[0.436]$ & $0.528[0.471]$ \\
\hline & & $\mathrm{CH} \nrightarrow \mathrm{US}$ & $0.218[0.641]$ & $0.189[0.666]$ \\
\hline & & $\mathrm{US} \nrightarrow \mathrm{CH}$ & $3.301[0.069]$ & $2.949[0.093]$ \\
\hline \multirow[t]{4}{*}{$\mathrm{HK}$} & \multirow[t]{4}{*}{2} & $\mathrm{US} \nrightarrow \mathrm{HK}$ & $8.760[0.013]$ & $3.853[0.029]$ \\
\hline & & $\mathrm{CH} \nrightarrow \mathrm{HK}$ & $3.182[0.204]$ & $1.325[0.277]$ \\
\hline & & $\mathrm{CH} \nrightarrow \mathrm{US}$ & $0.269[0.874]$ & $0.109[0.897]$ \\
\hline & & $\mathrm{US} \rightarrow \mathrm{CH}$ & $8.437[0.015]$ & $3.699[0.033]$ \\
\hline \multirow{4}{*}{$\begin{array}{l}\text { TAI } \\
\text { (based upon } \\
\text { VECM) }\end{array}$} & \multirow[t]{4}{*}{4} & $\mathrm{US} \nrightarrow \mathrm{AI}$ & $11.180[0.011]$ & $3.038[0.041]$ \\
\hline & & $\mathrm{CH} \nrightarrow \mathrm{TAI}$ & $8.792[0.032]$ & $2.333[0.089]$ \\
\hline & & $\mathrm{CH} \nrightarrow \mathrm{US}$ & $1.213[0.750]$ & $0.299[0.826]$ \\
\hline & & $\mathrm{US} \rightarrow \mathrm{CH}$ & $11.589[0.009]$ & $3.162[0.035]$ \\
\hline \multirow[t]{4}{*}{ SIN } & \multirow[t]{4}{*}{1} & $\mathrm{US} \nrightarrow \mathrm{SIN}$ & $4.840[0.028]$ & $4.389[0.042]$ \\
\hline & & $\mathrm{CH} \nrightarrow \mathrm{SIN}$ & $0.000[0.991]$ & $0.000[0.991]$ \\
\hline & & $\mathrm{CH} \nrightarrow \mathrm{US}$ & $0.333[0.564]$ & $0.289[0.593]$ \\
\hline & & $\mathrm{US} \nrightarrow \mathrm{CH}$ & $4.195[0.041]$ & $3.780[0.058]$ \\
\hline \multirow[t]{5}{*}{ EAEC } & \multirow[t]{5}{*}{3} & $\mathrm{US} \rightarrow \mathrm{EAEC}$ & $10.124[0.018]$ & $2.794[0.053]$ \\
\hline & & $\mathrm{CH} \nrightarrow \mathrm{EAEC}$ & $4.236[0.237]$ & $1.103[0.359]$ \\
\hline & & $\mathrm{CH} \nrightarrow \mathrm{US}$ & $1.017[0.797]$ & $0.257[0.856]$ \\
\hline & & $\mathrm{EAEC} \rightarrow \mathrm{CH}$ & $0.766[0.857]$ & $0.193[0.901]$ \\
\hline & & $\mathrm{US} \rightarrow \mathrm{CH}$ & $9.530[0.023]$ & $2.615[0.065]$ \\
\hline
\end{tabular}

Note: Figures in [ ] refer to the marginal significance level 
Table 6. Granger Causality Test (vis-à-vis Europe)

\begin{tabular}{|c|c|c|c|c|}
\hline Country & Lag Order & Null Hypothesis & $\begin{array}{l}\text { Likelihood Ratio } \\
\text { Test Statistic }\left(\chi^{2}\right)\end{array}$ & F-statistic \\
\hline \multirow[t]{4}{*}{ MAL } & \multirow[t]{4}{*}{4} & EUR $\nrightarrow$ MAL & $7.347[0.119]$ & $1.366[0.265]$ \\
\hline & & $\mathrm{CH} \rightarrow \mathrm{MAL}$ & $2.297[0.681]$ & 0.407 [0.803] \\
\hline & & $\mathrm{CH} \nrightarrow \mathrm{EUR}$ & $5.856[0.210]$ & $1.073[0.384]$ \\
\hline & & $\mathrm{EUR} \nrightarrow \mathrm{CH}$ & $6.176[0.186]$ & $1.135[0.356]$ \\
\hline \multirow[t]{4}{*}{ THA } & \multirow[t]{4}{*}{1} & EUR $\nrightarrow$ THA & $0.588[0.443]$ & $0.512[0.478]$ \\
\hline & & $\mathrm{CH} \nrightarrow \mathrm{THA}$ & $0.489[0.484]$ & $0.425[0.518]$ \\
\hline & & $\mathrm{CH} \nrightarrow \mathrm{EUR}$ & $2.346[0.126]$ & $2.077[0.157]$ \\
\hline & & $\mathrm{EUR} \nrightarrow \mathrm{CH}$ & $0.010[0.921]$ & 0.009 [0.927] \\
\hline \multirow[t]{4}{*}{ PHI } & \multirow[t]{4}{*}{3} & EUR $\rightarrow$ PHI & $2.781[0.427]$ & $0.714[0.550]$ \\
\hline & & $\mathrm{CH} \nrightarrow \mathrm{PHI}$ & $0.368[0.948]$ & 0.090 [0.965] \\
\hline & & $\mathrm{CH} \nrightarrow \mathrm{EUR}$ & $2.087[0.555]$ & $0.532[0.663]$ \\
\hline & & $\mathrm{EUR} \nrightarrow \mathrm{CH}$ & $5.629[0.131]$ & $1.486[0.233]$ \\
\hline \multirow[t]{5}{*}{ KOR } & \multirow[t]{5}{*}{1} & EUR $\nrightarrow$ KOR & $0.003[0.957]$ & $0.003[0.960]$ \\
\hline & & $\mathrm{CH} \nrightarrow \mathrm{KOR}$ & $0.222[0.637]$ & $0.193[0.663]$ \\
\hline & & $\mathrm{CH} \nrightarrow \mathrm{EUR}$ & $2.504[0.114]$ & $2.220[0.143]$ \\
\hline & & $\mathrm{EUR} \nrightarrow \mathrm{CH}$ & $0.052[0.820]$ & $0.045[0.833]$ \\
\hline & & $\mathrm{KOR} \nrightarrow \mathrm{CH}$ & $0.114[0.736]$ & 0.099 [0.755] \\
\hline \multirow[t]{5}{*}{ JAP } & \multirow[t]{5}{*}{3} & EUR $\nrightarrow$ JAP & $0.864[0.834]$ & $0.218[0.883]$ \\
\hline & & $\mathrm{CH} \nrightarrow \mathrm{JAP}$ & $2.353[0.502]$ & $0.602[0.618]$ \\
\hline & & $\mathrm{CH} \nrightarrow \mathrm{EUR}$ & $4.480[0.214]$ & $1.170[0.334]$ \\
\hline & & $\mathrm{EUR} \nrightarrow \mathrm{CH}$ & $2.625[0.453]$ & $0.673[0.574]$ \\
\hline & & $\mathrm{JAP} \nrightarrow \mathrm{CH}$ & $3.089[0.378]$ & $0.796[0.504]$ \\
\hline \multirow[t]{4}{*}{ IND } & \multirow[t]{4}{*}{3} & EUR $\rightarrow$ IND & $5.102[0.164]$ & $1.340[0.275]$ \\
\hline & & $\mathrm{CH} \nrightarrow \mathrm{IND}$ & $0.730[0.866]$ & 0.184 [0.907] \\
\hline & & $\mathrm{CH} \nrightarrow \mathrm{EUR}$ & $4.829[0.185]$ & $1.265[0.300]$ \\
\hline & & $\mathrm{EUR} \nrightarrow \mathrm{CH}$ & $4.267[0.234]$ & $1.112[0.356]$ \\
\hline \multirow[t]{4}{*}{ HK } & \multirow[t]{4}{*}{1} & $\mathrm{EUR} \nrightarrow \mathrm{HK}$ & $1.549[0.213]$ & $1.361[0.250]$ \\
\hline & & $\mathrm{CH} \nrightarrow \mathrm{HK}$ & $3.474[0.062]$ & $3.109[0.085]$ \\
\hline & & $\mathrm{CH} \rightarrow \mathrm{EUR}$ & $2.265[0.132]$ & $2.084[0.164]$ \\
\hline & & $\mathrm{EUR} \nrightarrow \mathrm{CH}$ & $0.210[0.647]$ & $0.182[0.671]$ \\
\hline \multirow[t]{4}{*}{ TAI } & \multirow[t]{4}{*}{1} & EUR $\rightarrow$ TAI & $2.977[0.084]$ & $2.681[0.110]$ \\
\hline & & $\mathrm{CH} \nrightarrow \mathrm{TAI}$ & $0.298[0.585]$ & $0.259[0.613]$ \\
\hline & & $\mathrm{CH} \rightarrow \mathrm{EUR}$ & $2.550[0.110]$ & $2.261[0.140]$ \\
\hline & & $\mathrm{EUR} \nrightarrow \mathrm{CH}$ & $0.616[0.433]$ & $0.536[0.468]$ \\
\hline \multirow[t]{4}{*}{ SIN } & \multirow[t]{4}{*}{1} & EUR $\rightarrow$ SIN & $0.058[0.810]$ & $0.050[0.824]$ \\
\hline & & $\mathrm{CH} \nrightarrow \mathrm{SIN}$ & $0.121[0.728]$ & 0.105 [0.747] \\
\hline & & $\mathrm{CH} \rightarrow \mathrm{EUR}$ & $1.803[0.179]$ & $1.588[0.214]$ \\
\hline & & $\mathrm{EUR} \nrightarrow \mathrm{CH}$ & $0.075[0.785]$ & $0.065[0.801]$ \\
\hline \multirow[t]{5}{*}{ EAEC } & \multirow[t]{5}{*}{3} & EUR $\nrightarrow$ EAEC & $0.640[0.887]$ & $0.161[0.922]$ \\
\hline & & $\mathrm{CH} \rightarrow \mathrm{EAEC}$ & $2.495[0.476]$ & $0.639[0.594]$ \\
\hline & & $\mathrm{CH} \rightarrow \mathrm{EUR}$ & $4.522[0.210]$ & $1.181[0.329]$ \\
\hline & & $\mathrm{EAEC} \rightarrow \mathrm{CH}$ & $2.920[0.404]$ & $0.751[0.528]$ \\
\hline & & $\mathrm{EUR} \nrightarrow \mathrm{CH}$ & $2.660[0.447]$ & $0.682[0.568]$ \\
\hline
\end{tabular}

Note: Figures in [ ] refer to the marginal significance level 


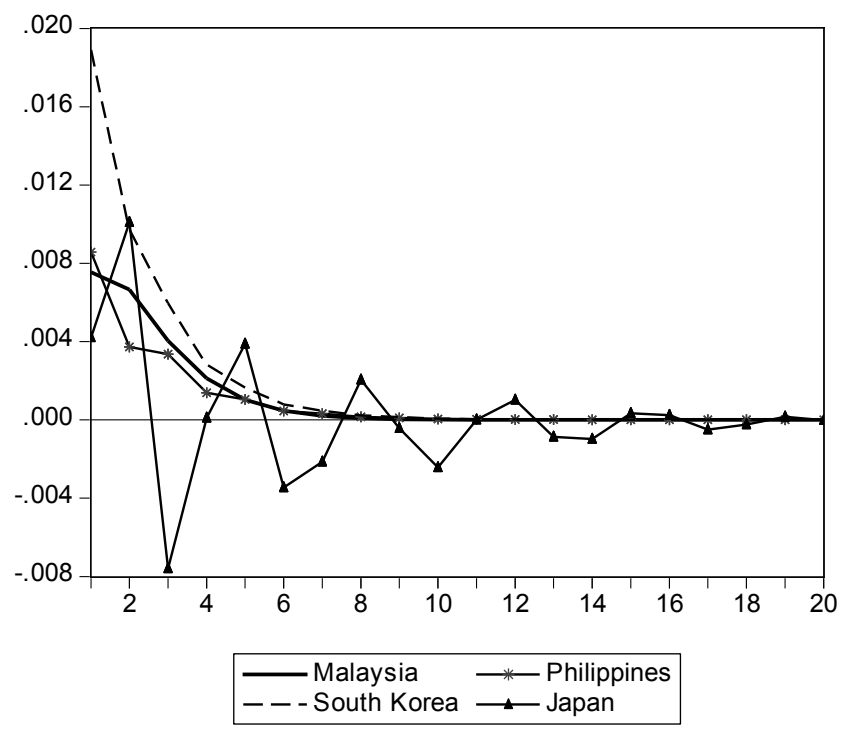

Figure 1. Generalized Impulse Responses to One SE Shock in the US Equation Source: authors' own

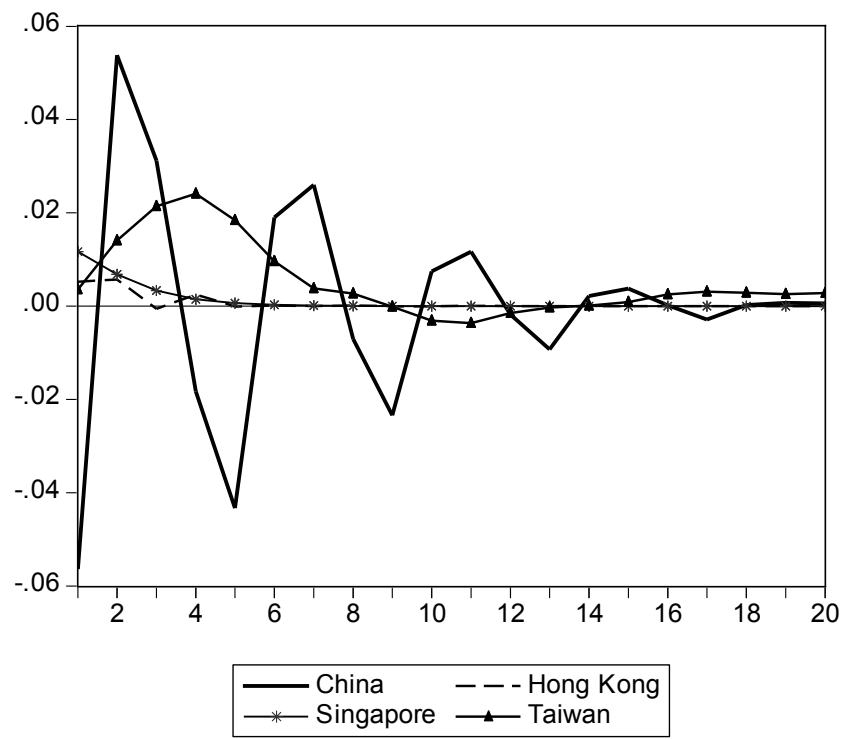

Figure 2. Generalized Impulse Responses to One SE Shock in the US Equation Source: authors' own 